\title{
An end too soon?
}

Cite as: CMAJ 2022 February 22;194:E262-3. doi: 10.1503/cmaj.211748

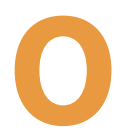

ne October clinic afternoon, I met $M^{m e} D$, an impeccably dressed woman in her seventies with a heavy French accent. I learned that roughly nine months earlier, she had noticed a new dimpling within a longstanding area of thickening in her right breast. She told me that years ago, a seat belt had saved her life but damaged her breast tissue, and a number of physicians and mammograms over the years had never raised any concerns. With the new dimpling, she had felt her breast becoming firmer and inexorably more deformed. Then a thin red line in the skin had become thickened and started oozing malodourously, triggering low-grade nausea that she couldn't shake. She finally went to the doctor who quickly surmised the problem and ordered a confirmatory mammogram and biopsy. A bone scan found the metastases that accounted for the discomfort in her upper back and left hip, which had led her to use a cane.

When I walked into the clinic room that afternoon, I had not been expecting to find such an elegantly dressed, superbly coiffed and glamorously smiling woman. $\mathrm{M}^{\text {me }} \mathrm{D}$ was radiant in her purples, blacks and golds, shimmering against the dreary backdrop of the hospital-beige examination room. Her jewellery came as close to sparkling as possible under the dismal fluorescent lighting. Throughout our conversation she dropped hints of an interesting life spent travelling the world, perhaps sharing more with me than she might have with others because we were able to converse in her native language.

I wondered how she had ended up in a remote, half-abandoned fishing village in rural Nova Scotia, a town I had driven through many times to admire the handsome yet increasingly dilapidated grand homes facing the water. As far as I could glean, she lived there alone, without a partner or close friends. I could easily imagine sea captains once casting covetous eyes on her as she strolled through the single main street on her way to the general store for supplies. There was no doubt that in her day, she would have stirred interest wherever she went.

Her breast was stretched tight by disease, with a gaping wound oozing the creamy yellow-green slime of a cancerous infection. A mixed dressing of toilet paper, gauze squares and imperfectly applied scotch tape was barely hanging on, threatening to unleash the toxic sludge through to her high-end clothing. It was clear to me that her nausea was likely caused by the eye-watering odour I was now experiencing.

Focusing on the feasible, I discussed the nature of her condition and the palliative intent of all treatment options. With endocrine therapy, her cancer likely could be meaningfully controlled without exposing her to the many adverse effects of chemotherapy, an option she dismissed as soon as I mentioned it. $\mathrm{M}^{\mathrm{me}} \mathrm{D}$ left that day with a prescription for antibiotics and an aromatase inhibitor as well as a low-dose narcotic to help with her back pain. I said that I would call her in three weeks and faxed a palliative care consultation request to one of my colleagues for wound and further supportive care needs. My hope was that she would respond quickly to the medication, her symptoms would improve and care intensity could de-escalate.

Two weeks after seeing her, I received a call from my colleague. $\mathrm{M}^{\mathrm{me}} \mathrm{D}$ was doing well. Supplied with appropriate dressings and instruction, she was taking much better care of the wound and had noticed that the oozing discharge had begun to lessen. She still used a cane but reported less pain. This exceeded even my optimistic expectations and further supported my hope that she had a chance of longterm disease control.

One week later, I was checking voicemail messages in the office:

"Cher docteur, it is $M^{\text {me }} D$. Thank you for the medicine - it has helped. I will stay on it until the end, which will be on November twentieth. Merci infiniment. Bonjour."

I was stunned.

Before the era of modern cancer medicine, the lines between "active treatment" and "symptomatic and supportive care" were sharp and often unequivocal. To paraphrase Thomas Hobbes, for many with metastatic disease, life was nasty, brutish and short, with the concept of "palliative chemotherapy" oxymoronic at best.

Coincident with treatment developments has been the addition of palliative care alongside active cancer treatment. This has been shown to improve quality of life as well as survival outcomes. ${ }^{1,2}$ Thus, as time under treatment has lengthened, care under treatment has expanded. The "us" and "them" that historically served as the basis for professional relationships between medical oncology and palliative care has been largely replaced by "we," although this is sometimes more aspirational than factual.

Despite this, we still have patients who suffer greatly from the combination of disease and treatment, and there are situations where there are simply not enough milligrams of narcotic, steroids or psychotropes to dull the pain, stimulate 
appetite or soothe existential distress. It is when reaching the limits of what supportive care can provide that medical assistance in dying (MAiD) is often conceived of as a best option. For those with a treatable active cancer with realistic expectations of disease control and maintenance or improvement in quality of life, it is uncommon to be asked about assisted dying as the first, and final, option.

I listened to $\mathrm{M}^{\mathrm{me}} \mathrm{D}$ 's message several times over the next few days, trying to understand how I felt about her decision. She was obviously a highly intelligent woman, fully capable of making decisions about her health care and life. Her condition was eventually terminal and she met all the legal criteria for MAiD. At our first and only meeting, she had told me that she had lived a full and interesting life and she was not afraid of death in the least. We had left with a clear plan and a viable path that many others would have loved to be able to walk. I had answered her question regarding prognosis when I said that it was usually measured in single-digit years, but now I wondered if she had heard anything beyond my prefacing comment that she would never actually be cured of her disease. I kept searching for clues to try and understand her decision and to ease my unsettled thoughts that it was something
I had said or implied that had led her to what was, in my opinion, such a premature decision. For $\mathrm{M}^{\mathrm{me}} \mathrm{D}$, death was the first answer, not the last alternative - an end to be embraced rather than actively battled.

Months later, I was driving through the village where she had lived, and I found her house. I wasn't surprised that it was a stunning captain's manse with a handsome wide porch facing the water. Huge windows sparkled in the late afternoon sun, and a room on the second floor had a small balcony upon which I imagined her sitting out in the mornings with her café au lait, taking in the expansive ocean view and salty breeze. As I admired the scene, I noticed that the gutters needed replacing; one had become detached and hung crazily off the side. As well, a few of the front steps had rotted through because of the constant salty dew, and the chimney was crumbling.

I wondered if $\mathrm{M}^{\mathrm{me}} \mathrm{D}$ had noticed these same signs of impending collapse and, knowing that nothing I could do would truly fix her, chose to end her life on her own terms and before both disease and time left her as ravaged as the old house before me.

I got back in the car and continued down the slowly curving road, the glitter of the sun setting over the water reminding me of her sparkle. The rustic beauty of the old fishing town quietly extinguished in the rear-view mirror as some of the unease that had lingered since her voice message began to lift and the ocean stretched out on either side of me.

\section{Daniel Rayson MD}

Division of Medical Oncology, Department of Medicine, Queen Elizabeth II Health

Sciences Centre and Dalhousie University, Halifax, NS

\section{References}

1. Mathews J, Hannon B, Zimmermann C. Models of integration of specialized palliative care with oncology. Curr Treat Options Oncol 2021;22:44.

2. Temel JS, Greer JA, Muzikansky A, et al. Early palliative care for patients with metastatic non-small-cell lung cancer. N Engl J Med 2010;363:733-42.

This article has been peer reviewed.

$M^{m e} D$ is a composite of numerous patients, as are the details of her care and decision.

Content licence: This is an Open Access article distributed in accordance with the terms of the Creative Commons Attribution (CC BY-NC-ND 4.0) licence, which permits use, distribution and reproduction in any medium, provided that the original publication is properly cited, the use is noncommercial (i.e., research or educational use), and no modifications or adaptations are made. See: https://creativecommons.org/ licenses/by-nc-nd/4.0/ 